\title{
Geochemical study of lower Eocene volcanic ash layers from the Alpine Anthering Formation, Austria
}

\author{
Heinz Huber, ${ }^{1,2}$ Christian KoeberL ${ }^{1 *}$ and HANS EGGER ${ }^{3}$ \\ ${ }^{1}$ Institute of Geochemistry, University of Vienna, Althanstrasse 14, A-1090 Vienna, Austria \\ ${ }^{2}$ Atominstitut, Technical University of Vienna, Stadionallee 2, A-1020 Vienna, Austria \\ ${ }^{3}$ Geological Survey of Austria, Rasumofskygasse 23, A-1031 Vienna, Austria
}

(Received May 30, 2002; Accepted September 3, 2002)

\begin{abstract}
Samples of bentonite layers from altered volcanic ash layers of the Anthering Formation in Salzburg, Austria, which most likely covers the Paleocene/Eocene boundary, were analyzed for their chemical composition. The results of the major and trace element determination confirm the previously suggested appearance from at least two different primary localities. One sample has low abundances in $\mathrm{TiO}_{2}$ and $\mathrm{Ir}$ ( 0.77 wt. \% and $47 \pm 16 \mathrm{ppt}$, respectively), whereas all others have iridium concentrations between 200$450 \mathrm{ppt}$. On the basis of the chemical composition the bentonite layers are distant equivalents of coeval ash deposits from the Fur and Balder Formation in Denmark and the North Sea, respectively, as was suggested from petrological and mineralogical investigations.
\end{abstract}

\section{INTRODUCTION}

The Rhenodanubian Flysch zone comprises an imbricated thrust pile trending parallel to the northern margin of the Eastern Alps. The flysch sediments (Barremian-Ypresian) were deposited in an abyssal environment at the northwestern Tethyan margin (Egger et al., 2002). The youngest deposits of the Rhenodanubian Flysch are exposed close to the small village of Anthering, 10 $\mathrm{km}$ north of the town Salzburg (see Fig. 1). This expanded and continuous section contains deposits from calcareous nannoplankton Zones NP9 and NP10 in the standard nannoplankton zonation of Martini (1971). In the upper part of Zone NP9 it displays the global negative carbon isotope excursion (Egger et al., 2000). This prominent decrease in the ${ }^{13} \mathrm{C} /{ }^{12} \mathrm{C}$ ratio of global carbon reservoirs took place around $55 \mathrm{Ma}$ ago, and is explained as the result of massive methane release due to the dissociation of gas hydrates (see Katz et al., 1999, for a review). Most likely, this isotope event will be assigned to represent the Paleocene/Eoceneboundary, because marine and terrestrial sections can be correlated by this excursion; however, up to now the Paleocene/Eocene-boundary still awaits a clear definition (see Aubry, 2000, for a review).

The $250 \mathrm{~m}$ thick deposits of the Anthering section are composed of carbonate-bearing mudturbidites with intervening hemipelagic shales, which indicate deposition below the calcite compensation depth (Egger et al., 1997). About $50 \mathrm{~m}$ above the onset of the negative carbon isotope excursion 23 closely spaced layers of pure Femontmorillonite were found which are interpreted as volcanic ashes (Egger, 1995). These bentonites are restricted to a $40 \mathrm{~m}$ thick part of the section that represents the lower part of calcareous nannoplankton Zone NP10 (sub-Zone NP10a in the refined zonation of Aubry, 1996), as shown in Figs. 2 and 3. The latter author has roughly estimated the duration of this sub-Zone at $630 \mathrm{ky}$ by using sedimentation rates. Immobile element concentrations indicate a basaltic composition of the

*Corresponding author (e-mail: christian.koeberl@univie.ac.at) 


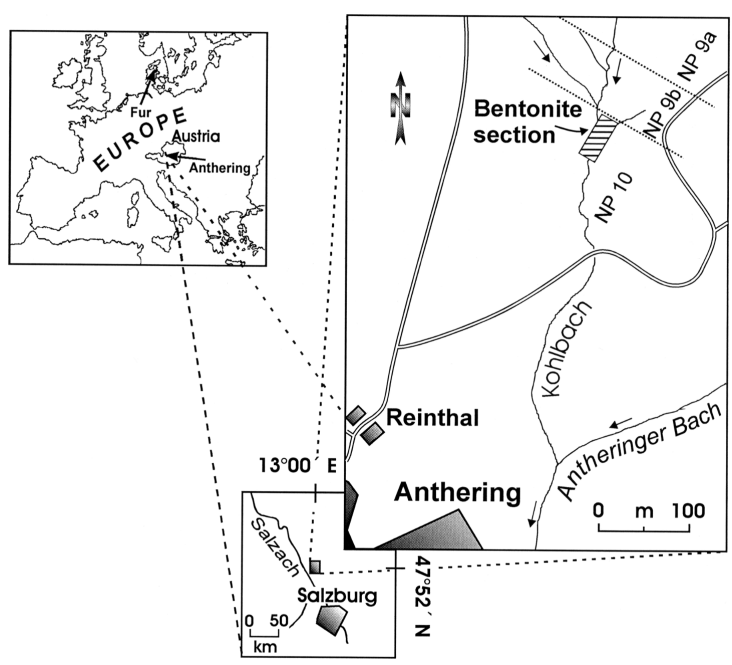

Fig. 1. Geographical map of the Tethyan Anthering Formation, Austria, with location of the outcrops. Bentonites were sampled from the bank of the meandering creek of the Kohlbach. For details on the location see Egger (1995). Included are the NP (nannoplankton) zones of the outcrop.

ash-producing magma (Egger et al., 2000) which is unusual for a pronounced phase of explosive volcanism. Ashes of a similar composition are long known from the North Sea region (Bøggild, 1918), in particular from the Fur Formation in Denmark. Ritchie and Hitchen (1996) suggested sub-aerial volcanism with possible seamounts as source for the phreatomagmatic eruption.

Within the $60 \mathrm{~m}$ thick Fur Formation 179 ash layers occur (for a review see Nielsen and Heilmann-Clausen, 1988), which originated from intense volcanism associated with the opening of the North Atlantic (Knox and Morton, 1988; Knox, 1998). Equivalents of these ashes have also been found to the southwest of Ireland, at DSDP Site 550, where they are restricted to Zone NP10 (Knox, 1985). The Fur Formation consists of claystone and diatomite and is devoid of carbonate; therefore, biostratigraphy by means of calcareous nannoplankton is not possible. However, it was possible to correlate the dinoflagellate zonation of the North Sea region with the dinoflagellate record at Anthering (Heilmann-Clausen and Egger, a)

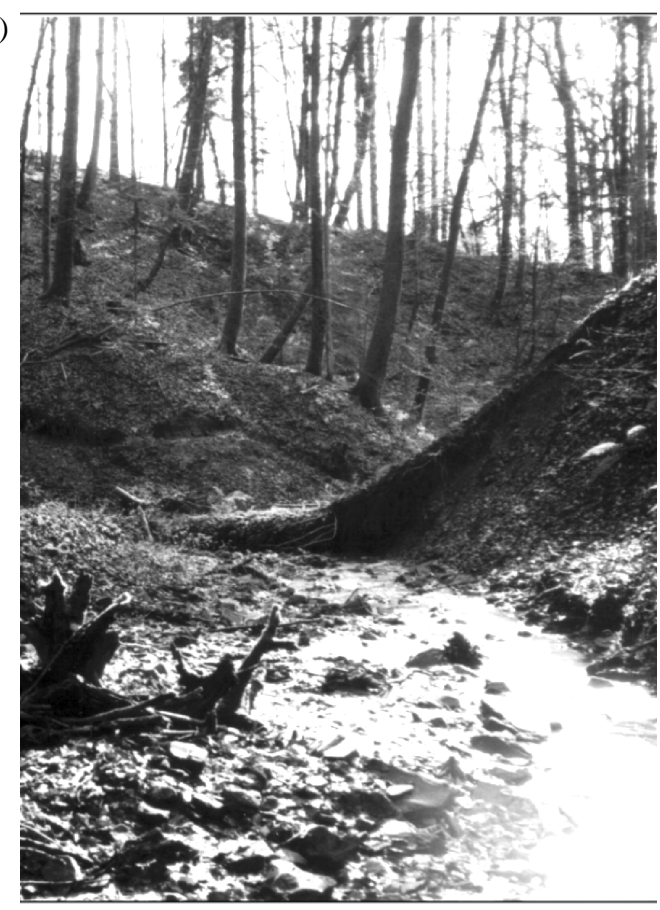

b)

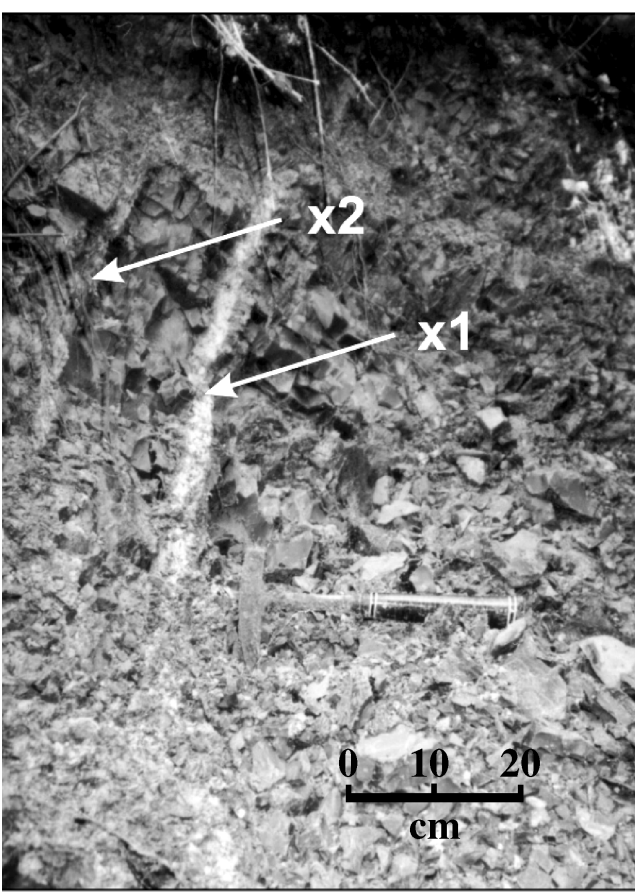

Fig. 2. a) Photograph showing the meandering Kohlbachgraben near Anthering, Austria. b) Close-up of the about 3-cm-wide lowermost bentonite layer x1 (whitish) and the thinner $x 2$ layer. 


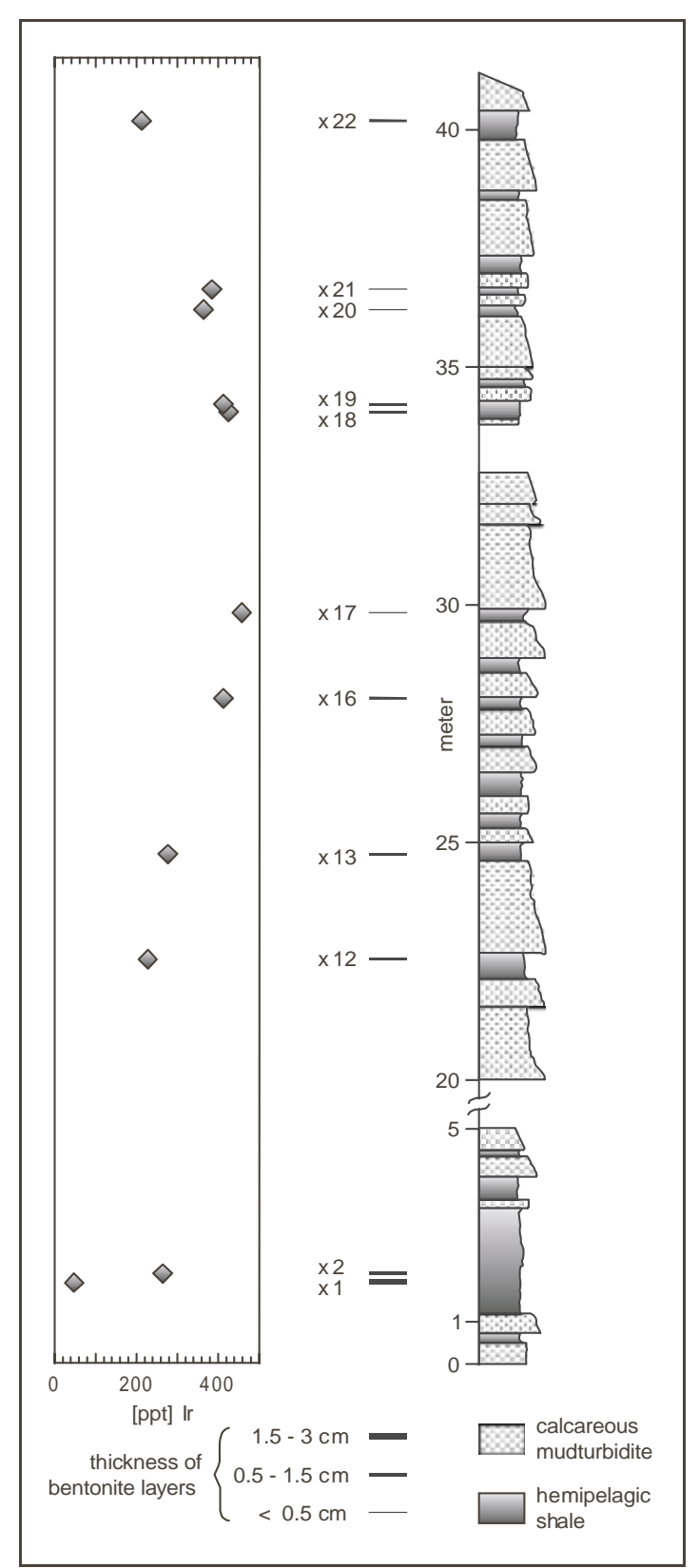

Fig. 3. Part of the Late Palaeocene-Early Eocene stratigraphic section at Anthering, including the iridium abundances of the bentonite layers. The whole section is a part of zone NP 10a and comprises only calcareous mudturbidites, bentonites and claystone layers with infrequent intercalated black shales. Thickness of bentonite layers is generally less than $1.5 \mathrm{~cm}$, with $x 1$ as the only exception $(3 \mathrm{~cm})$.
1997) and, thus, the identical stratigraphic position of the ash-deposits at Fur and Anthering could be confirmed. Equivalent bentonite layers were also found in the Gurnigel-Schlieren-Wägital Flysch (Winkler et al., 1985) south of Zurich and recently in another Tethyan section in Slovenia (Dolenec et al., 2000).

Geochemical analyses of the Danish bentonites showed enrichments in iridium from below detection limit to up to $300 \mathrm{ppt}$ (Schmitz and Asaro, 1996). Iridium contents between 200 and 300 ppt were also reported from the Balder formation in the North Sea (Elliot et al., 1992). Iridium is a highly siderophile (and mostly immobile) element that is usually taken as a tracer of an extraterrestrial (meteoritic) component (see, e.g., Koeberl, 1998; Montanari and Koeberl, 2000 and references therein). The presence of elevated Ir contents, and near-meteoritic interelement ratios of the platinum-group elements (PGEs), in sediments marking the Cretaceous-Tertiary boundary, was the key evidence for the discovery of a large-scale (cometary or asteroidal) impact event at that time, 65 million years ago (see review in Montanari and Koeberl, 2000). Since then, several other mass extinctions were also linked to possible impact events, usually via the search for Ir anomalies in the geological record (e.g., Olsen et al., 2002). However, in some rare cases low Ir abundances (less than $0.5 \mathrm{ppb}$ ) have been linked to volcanic (mantle) sources as well (e.g., Zoller et al., 1983; Koeberl, 1989; Toutain and Meyer, 1989), which was also the interpretation favored by Elliot $e t$ al. (1992) and Schmitz and Asaro (1996) for the bentonites from the Balder and Fur formations, respectively. In general Ir is not affected by weathering or diagenesis, although under certain conditions it and other PGEs are mobile as well, leading to changes in the interelement ratios (e.g., Colodner et al., 1992).

The purpose of this paper is to provide detailed geochemical data for the ash layers of the Anthering Formation, to confirm the correlation between the North Atlantic and the Tethyan section for these late Palaeocene bentonites by focusing on the trace element abundances, and, in 
particular, to discuss the iridium contents of these rocks.

\section{SAmples AND ANAlytical TeChniques}

Eleven samples from the Lower Eocene sequence of the Anthering Formation were analyzed. The stratigraphy in the Kohlbachgraben is difficult to follow due to the seasonal changing in the small riverbed. No sedimentary structures can be followed in the layers. The altered ashes of white to yellowish or ochre color are exposed in the meandering valley of the Kohlbach and have thicknesses of $3 \mathrm{~cm}$ and less (Fig. 2). Samples of about $100 \mathrm{~g}$ each were taken from a depth of $\sim 20 \mathrm{~cm}$ to avoid any contamination due to surface slumping and weathering. Samples were dried at $110^{\circ} \mathrm{C}$ for several days and manually crushed in a plastic wrap. Then they were powdered using an agate mortar and pestle and dried at $105^{\circ} \mathrm{C}$ to constant weight.

Major, minor, and trace element analysis were performed with X-ray fluorescence spectrometry (XRF) and instrumental neutron activation analysis (INAA). For INAA, aliquots of about $150 \mathrm{mg}$ of the powder were sealed in polyethylene (PE) capsules. Samples and standards (international certified geological reference material) were packed and enclosed in a large PE-vial for irradiation. The granitic standards AC-E and G-2 (Govindaraju, 1989) from the U.S. Geological Survey, the Allende meteorite standard reference powder (Jarosewich et al., 1987), and the mineralized gabbro PGE standard WMG-1 (CANMET, 1994) were used for quantification and to determine the accuracy of the analyses.

All samples were irradiated for 6 hours at the TRIGA Mark II reactor of the "Atominstitut der österreichischen Universitäten" in Vienna with a neutron flux of $2 \cdot 10^{12} \mathrm{~cm}^{-2} \mathrm{~s}^{-1}$. For further processing the irradiated samples were transported to the Institute of Geochemistry. Details on instrumentation, measuring procedures, evaluation of data, precision and accuracy of the INAA system are given by Koeberl (1993).

Because of the expected low concentrations of iridium, conventional INAA is not sufficient to yield usable abundance values. Thus, the iridium contents were determined using the multiparameter $\gamma-\gamma$ coincidence spectrometry system at the Institute of Geochemistry (Koeberl and Huber, 2000). The $\gamma$ - $\gamma$ coincidence method is specifically designed to determine iridium contents in the sub-parts-per-billion (sub-ppb) range. Compared to other analytical techniques, such as radiochemical NAA or ICP-MS, the coincidence spectrometry has one major advantage: no dissolution or other chemical treatment of the samples is required, and, therefore, possible contamination is avoided. Irrespective of the nature of the matrix good sensitivity and precision can be obtained even for small sample sizes (less than $100 \mathrm{mg}$ ).

For $\gamma-\gamma$ coincidence spectrometry, the eleven sample powders of about $150 \mathrm{mg}$ each, as well as a standard series, were sealed into Suprasil quartz glass tubes. For standards, finely powdered Allende meteorite reference sample (Jarosewich et al., 1987) was mixed with pure quartz powder to obtain a dilution series containing between 56 and $1350 \mathrm{ppt}$ iridium. Samples and standards were wrapped in aluminum foil, packed in an aluminum capsule, and irradiated for 48 hours at the KFKI reactor of the Institute of Isotopes, Budapest, Hungary, at a neutron flux of $7 \cdot 10^{13} \mathrm{~cm}^{-2} \mathrm{~s}^{-1}$. After a cooling period of three months standards and samples were measured for at least 12 up to 24 hours, depending on the signal to noise ratio of the spectrum. Regression analysis of the standard dilution series was done to obtain interpolated values of the standard peak volumes. The mean was used to perform the unknown-sample analysis as described above.

Major and trace element analysis by XRF was performed at the University of the Witwatersrand, Johannesburg, South Africa, using a Philips PW 1400 spectrometer. Aliquots of $5 \mathrm{~g}$ each were heated in silica crucibles at $1000^{\circ} \mathrm{C}$ for 6 hours to determine the loss on ignition (LOI). Major, minor, and trace element abundances were determined according to procedures described in Buchanan et al. (1999) and Reimold et al. (1994). 
Table 1. Major and trace element abundances of bentonites from the Anthering Formation. All $\mathrm{Fe}$ as $\mathrm{Fe}{ }_{2} \mathrm{O}_{3}$, all major elements in wt.\%, all trace element abundances in $\mu \mathrm{g} / \mathrm{g}$ (ppm) except as indicated. Major elements, V, Cu, $\mathrm{Sr}, \mathrm{Y}$, and $\mathrm{Nb}$ determined by XRF, all other trace element contents by INAA, except Ir by $\gamma-\gamma$-coincidence spectrometry. Data on precision and accuracy are described in Koeberl (1993) for the INAA method and in Reimold et al. (1994) for XRF-analyses.

\begin{tabular}{|c|c|c|c|c|c|c|c|c|c|c|c|}
\hline Sample & $x 1$ & $\mathrm{x} 2$ & $x 12$ & $x 13$ & $x 16$ & $\mathrm{x} 17$ & $\mathrm{x} 18$ & $\mathrm{x} 19$ & $\mathrm{x} 20$ & $\mathrm{x} 21$ & $\mathrm{x} 22$ \\
\hline $\mathrm{SiO}_{2}$ & 52.8 & 48.1 & 50.2 & 51.1 & 48.8 & 49.3 & 52.4 & 51.3 & 48.9 & 49.0 & 51.2 \\
\hline $\mathrm{TiO}_{2}$ & 0.77 & 6.39 & 3.57 & 3.40 & 3.24 & 3.18 & 3.44 & 3.43 & 3.91 & 3.78 & 3.99 \\
\hline $\mathrm{Al}_{2} \mathrm{O}_{3}$ & 18.9 & 18.4 & 19.1 & 18.7 & 18.5 & 18.0 & 18.1 & 18.0 & 18.7 & 18.7 & 18.2 \\
\hline $\mathrm{Fe}_{2} \mathrm{O}_{3}$ & 4.27 & 6.14 & 4.73 & 6.93 & 6.32 & 5.36 & 5.45 & 5.70 & 5.77 & 6.34 & 5.29 \\
\hline $\mathrm{MnO}$ & 0.04 & 0.06 & 0.04 & 0.04 & 0.05 & 0.03 & 0.04 & 0.08 & 0.05 & 0.10 & 0.02 \\
\hline $\mathrm{MgO}$ & 2.00 & 1.94 & 1.92 & 1.92 & 1.88 & 2.13 & 1.92 & 1.94 & 1.83 & 1.82 & 1.94 \\
\hline $\mathrm{CaO}$ & 2.13 & 2.06 & 3.31 & 3.01 & 3.70 & 2.76 & 2.42 & 2.40 & 2.85 & 2.87 & 2.46 \\
\hline $\mathrm{Na}_{2} \mathrm{O}$ & 0.40 & 0.12 & 1.02 & 1.12 & 1.03 & 0.36 & 0.35 & 0.33 & 0.62 & 0.60 & 0.45 \\
\hline $\mathrm{K}_{2} \mathrm{O}$ & 0.67 & 0.44 & 0.60 & 0.68 & 0.72 & 0.74 & 1.18 & 0.99 & 0.47 & 0.43 & 0.40 \\
\hline $\mathrm{P}_{2} \mathrm{O}_{5}$ & 0.07 & 0.16 & 0.23 & 0.30 & 0.32 & 0.23 & 0.22 & 0.18 & 0.30 & 0.23 & 0.22 \\
\hline Loi & 18.0 & 16.1 & 14.6 & 12.8 & 13.4 & 17.0 & 14.4 & 15.4 & 16.5 & 16.1 & 15.8 \\
\hline Total & 100.0 & 99.9 & 99.3 & 100.0 & 97.9 & 99.1 & 99.8 & 99.7 & 99.8 & 100.0 & 99.9 \\
\hline $\mathrm{Sc}$ & 6.42 & 25.9 & 38.8 & 27.6 & 26.9 & 28.7 & 23.7 & 26 & 35.3 & 29.7 & 34.5 \\
\hline V & 27 & 267 & 422 & 218 & 337 & 278 & n.d. & 279 & 421 & 378 & 412 \\
\hline $\mathrm{Cr}$ & 10 & 60 & 103 & 51 & 85 & 113 & 152 & 94 & 88 & 83 & 50 \\
\hline Co & 2.38 & 8.07 & 10.1 & 23.6 & 42.2 & 4.53 & 11.2 & 55.6 & 21.6 & 50.7 & 13.5 \\
\hline $\mathrm{Ni}$ & 22 & 42 & 64 & 63 & 116 & 25 & 119 & 59 & 51 & 52 & 39 \\
\hline $\mathrm{Cu}$ & $<2$ & 124 & 220 & 146 & 305 & 193 & n.d. & 206 & 233 & 244 & 153 \\
\hline $\mathrm{Zn}$ & 50 & 68 & 120 & 123 & 259 & 151 & 126 & 118 & 104 & 107 & 87 \\
\hline As & $<1$ & 49.3 & 14.1 & 18.5 & 17 & 0.6 & 9.4 & 7.95 & 15.4 & 11.3 & 6.8 \\
\hline $\mathrm{Br}$ & 0.65 & 1.76 & 0.93 & 1.18 & 0.61 & 1.02 & 1.02 & 1.07 & 1.34 & 1.24 & 0.78 \\
\hline $\mathrm{Rb}$ & 23 & 21 & 16 & 21 & 25 & 28 & 50 & 47 & 15 & 19 & 15 \\
\hline $\mathrm{Sr}$ & 108 & 91 & 238 & 168 & 348 & 127 & n.d. & 114 & 146 & 130 & 115 \\
\hline $\mathrm{Y}$ & 40 & 15 & 28 & 33 & 39 & 22 & 44 & 35 & 52 & 33 & 40 \\
\hline $\mathrm{Zr}$ & 486 & 244 & 254 & 213 & 222 & 225 & 258 & 254 & 253 & 219 & 308 \\
\hline $\mathrm{Nb}$ & 146 & 33 & 27 & 31 & 30 & 28 & 36 & 34 & 34 & 30 & 35 \\
\hline $\mathrm{Sb}$ & 0.44 & 2.15 & 1.14 & 1.74 & 1.25 & 0.59 & 0.69 & 0.73 & 1.36 & 1.1 & 0.84 \\
\hline Cs & 1.18 & 1.23 & 0.73 & 1.28 & 1.42 & 1.30 & 3.42 & 2.81 & 0.69 & 0.83 & 0.76 \\
\hline $\mathrm{Ba}$ & 251 & 424 & 287 & 268 & 264 & 271 & 354 & 338 & 402 & 283 & 221 \\
\hline $\mathrm{La}$ & 63.6 & 13.0 & 22.2 & 25.1 & 27.7 & 20.1 & 37.5 & 28.4 & 30.3 & 23.1 & 22.7 \\
\hline $\mathrm{Ce}$ & 135 & 27.3 & 63.3 & 72.5 & 82.7 & 67.5 & 85.7 & 69.8 & 85.5 & 62.9 & 64.1 \\
\hline $\mathrm{Nd}$ & 53.1 & 16.5 & 37.4 & 40.0 & 41.7 & 35.9 & 53.8 & 38.4 & 52.5 & 40.0 & 40.2 \\
\hline $\mathrm{Sm}$ & 9.84 & 4.09 & 9.67 & 9.75 & 9.66 & 8.16 & 11.7 & 8.10 & 13.2 & 9.45 & 10.3 \\
\hline $\mathrm{Eu}$ & 2.42 & 1.03 & 3.39 & 3.28 & 2.97 & 2.18 & 3.22 & 2.30 & 4.49 & 2.79 & 3.56 \\
\hline Gd & 8.27 & 4.01 & 8.51 & 8.56 & 9.13 & 5.97 & 10.1 & 7.52 & 13.8 & 7.94 & 8.87 \\
\hline $\mathrm{Tb}$ & 1.31 & 0.68 & 1.35 & 1.39 & 1.54 & 0.88 & 1.63 & 1.22 & 2.27 & 1.26 & 1.40 \\
\hline $\mathrm{Tm}$ & 0.5 & 0.24 & 0.33 & 0.40 & 0.37 & 0.25 & 0.46 & 0.34 & 0.51 & 0.33 & 0.42 \\
\hline $\mathrm{Yb}$ & 3.09 & 1.45 & 1.86 & 2.27 & 2.03 & 1.47 & 2.72 & 1.93 & 2.75 & 1.88 & 2.43 \\
\hline $\mathrm{Lu}$ & 0.39 & 0.19 & 0.23 & 0.31 & 0.26 & 0.19 & 0.38 & 0.25 & 0.33 & 0.25 & 0.30 \\
\hline $\mathrm{Hf}$ & 17.7 & 5.68 & 6.93 & 5.65 & 5.22 & 5.24 & 6.14 & 6.21 & 6.63 & 6.04 & 8.09 \\
\hline $\mathrm{Ta}$ & 9.94 & 2.57 & 2.49 & 2.60 & 1.68 & 2.46 & 2.16 & 2.10 & 2.09 & 2.01 & 2.40 \\
\hline Ir (ppt) & $47 \pm 16$ & $264 \pm 37$ & $228 \pm 36$ & $276 \pm 38$ & $413 \pm 44$ & $460 \pm 50$ & $426 \pm 49$ & $418 \pm 44$ & $402 \pm 44$ & $385 \pm 43$ & $212 \pm 35$ \\
\hline $\mathrm{Au}(\mathrm{ppb})$ & 1 & 38 & 14 & 23 & 20 & 24 & 27 & 21 & 13 & 28 & 17 \\
\hline Th & 18.2 & 5.14 & 3.59 & 5.11 & 3.88 & 4.20 & 6.50 & 6.28 & 3.56 & 3.82 & 4.66 \\
\hline$U$ & 4.16 & 3.15 & 1.85 & 1.94 & 1.11 & 3.63 & 2.82 & 2.21 & 1.77 & 2.09 & 2.43 \\
\hline $\mathrm{Th} / \mathrm{U}$ & 4.38 & 1.63 & 1.94 & 2.63 & 3.50 & 1.16 & 2.30 & 2.84 & 2.01 & 1.83 & 1.92 \\
\hline $\mathrm{La} / \mathrm{Th}$ & 3.49 & 2.53 & 6.18 & 4.91 & 7.14 & 4.79 & 5.77 & 4.52 & 8.51 & 6.05 & 4.87 \\
\hline $\mathrm{Nb} / \mathrm{Y}$ & 3.65 & 2.20 & 0.96 & 0.94 & 0.77 & 1.27 & - & 0.97 & 0.65 & 0.91 & 0.88 \\
\hline $\mathrm{Zr} / \mathrm{Hf}$ & 27.5 & 43.0 & 36.7 & 37.7 & 42.5 & 42.9 & 42.0 & 40.9 & 38.2 & 36.3 & 38.1 \\
\hline $\mathrm{Hf} / \mathrm{Ta}$ & 1.78 & 2.21 & 2.78 & 2.17 & 3.11 & 2.13 & 2.84 & 2.96 & 3.17 & 3.00 & 3.37 \\
\hline $\mathrm{La} / \mathrm{Yb}$ & 20.6 & 9.0 & 11.9 & 11.1 & 13.6 & 13.7 & 13.8 & 14.7 & 11.0 & 12.3 & 9.3 \\
\hline $\mathrm{Eu} / \mathrm{Eu}^{*}$ & 0.82 & 0.78 & 1.14 & 1.10 & 0.97 & 0.95 & 0.91 & 0.90 & 1.04 & 0.98 & 1.12 \\
\hline $\mathrm{Ir} / \mathrm{Au}$ & 0.047 & 0.007 & 0.016 & 0.012 & 0.021 & 0.019 & 0.016 & 0.020 & 0.031 & 0.014 & 0.012 \\
\hline
\end{tabular}

n.d. = not determined $; \mathrm{Eu} / E u^{*}=E u_{n} /\left[\left(S m_{n}\right)\left(G d_{n}\right)\right]$. 


\section{RESULTS}

The results of our chemical analyses of eleven bentonite samples from the Anthering Formation are given in Table 1. The basaltic altered ashes have very similar $\mathrm{SiO}_{2}, \mathrm{Al}_{2} \mathrm{O}_{3}$, and $\mathrm{MgO}$ contents, with ranges of 48-53,18-19 and 1.8-2.1 wt.\%, respectively. Nevertheless, the $\mathrm{TiO}_{2}$ concentrations are somewhat more variable, with most samples (x12-x22) ranging from 3.18 to 3.99 wt.\%. Two samples have anomalous $\mathrm{TiO}_{2}$ contents: sample $\mathrm{x} 1$ is depleted $(0.77 \mathrm{wt} . \%)$ and sample $\mathrm{x} 2$ highly enriched (6.37 wt.\%). Correlating with $\mathrm{TiO}_{2}$ are also Sc, V, and Cr, whereas Hf, Ta, Th, and especially $\mathrm{Nb}$ can be used to distinguish the samples (see Fig. 4). The samples in the binary plot of $\mathrm{Nb}$ versus $\mathrm{TiO}_{2}$ are split into three different groups. The majority plots in the lower middle, whereas sample $\mathrm{x} 1$ and $\mathrm{x} 2$ show a total different behavior. Bentonite layer $\mathrm{x} 1$ is characterized by a distinct depletion in the contents of $\mathrm{TiO}_{2}$, $\mathrm{P}_{2} \mathrm{O}_{5}$, the transition metals $\mathrm{Sc}, \mathrm{V}, \mathrm{Cr}, \mathrm{Co}, \mathrm{Ni}, \mathrm{Zn}$, as well as $\mathrm{Ir}$ and $\mathrm{Au}$, in contrast to enrichments in the contents of the high field strength elements $\mathrm{Zr}, \mathrm{Nb}, \mathrm{Hf}, \mathrm{Ta}, \mathrm{Th}$, and the light rare earth ele-

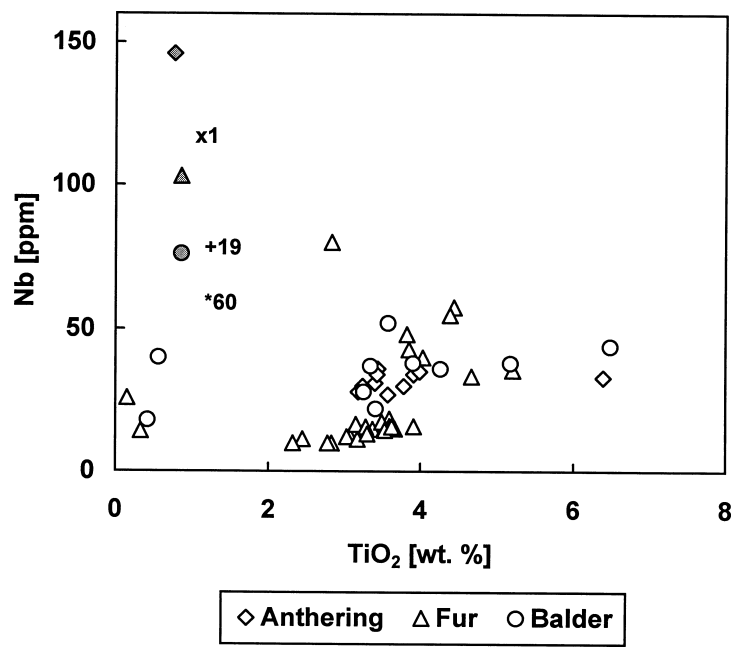

Fig. 4. Variation of $\mathrm{TiO}_{2}$ and $\mathrm{Nb}$ contents for bentonites from the Anthering, Fur, and Balder formations. The correlated samples $x 1,+19$ and $* 60$ are shown in dark grey. Data from Schmitz and Asaro (1996) for the Fur formation and Morton and Knox (1990) for Balder. ments (REE) La and Ce. Sample x 2 on the other hand is different to $\mathrm{x} 1$ not only on the basis of an elevated iridium abundance and reduced $\mathrm{Ir} / \mathrm{Au}$ ratio, but also regarding the distribution of other trace elements, e.g., the rare earth elements (REE). Figure 5 shows the $\mathrm{C} 1$-chondrite normalized REE distribution patterns for all bentonite samples. $\mathrm{x} 1$ and $\mathrm{x} 2$ have crustal patterns with negative Euanomalies, but $\mathrm{x} 2$ is generally depleted in all REE compared to $\mathrm{x} 1$. The other samples have much gentler slopes for the light REE and only minor positive or negative Eu anomalies. The stratigraphic distribution of iridium within the sequence studied is shown in Fig. 3 and indicates concentrations between $47 \pm 16(\mathrm{x} 1)$ and $460 \pm$ 50 ppt (x17), with most samples between 200 and $400 \mathrm{ppt}$. Ir/Au ratios vary between 0.01 and 0.05 with no correlation with stratigraphic height.

\section{Discussion}

The bentonite samples are highly altered volcanic ashes. They have chemical indices of alteration (CIA, by Nesbitt and Young, 1984) of 8090\%. Their REE patterns (Fig. 5a) are typical for tholeiitic basalts with slight depletions of the heavy REE. A similar differentiation was also observed in the Danish ash series of the Balder formation with comparable $(\mathrm{La} / \mathrm{Yb})_{\mathrm{N}}$ and $(\mathrm{La} /$ $\mathrm{Sm})_{\mathrm{N}}$ ratios (Morton and Knox, 1990). According to Fig. 5b, the majority of samples analyzed have a similar REE composition indicating similar provenance. Previous studies on the chemical differentiation of the REE due to diagenesis of volcanic ash layers report varying scenarios ranging from minor enrichments in the light REE and depletion of the heavy REE (Christidis, 1998) to minor depletions of the light REE (Zielinski, 1982). The observation that the Eu-anomaly shows only a limited range (positive and negative anomalies) for most samples could indicate alteration phenomena only (see McLennan, 1989), and makes fractionation of biotite or plagioclase in the primary source more unlikely. Additionally, the REE pattern looks similar to that of, e.g., rocks from the Vesteris seamount off East-Greenland 
(Haase and Devey, 1994).

The series of comparable altered ashes from Anthering and from the Fur formation (Schmitz and Asaro, 1996) have previously been correlated on the basis of the uppermost occurring of the dinoflagellate species Apectodinium augustum (Egger et al., 2000) and on the distribution of the elements $\mathrm{Nb}, \mathrm{Y}, \mathrm{Zr}$, and Ti. The discrimination diagram of $\mathrm{Nb} / \mathrm{Y}-\mathrm{Zr} / \mathrm{TiO}_{2}$ (Fig. 6) by Winchester and Floyd (1977) was used for the determination of the magma origin of the altered ashes showing that the samples plot in two groups: the majority of bentonites fall within the alkali basalt field, whereas $\mathrm{x} 1$ has a trachytic composition. Yttrium is generally considered to be as immobile as the other three elements used in the diagram, but under certain weathering conditions this element can be mobilized during alteration (e.g., Larsen et al., 1998, Christidis, 1998) or it can be concentrated in biogenic phosphate layers (Egger et al., 2000). This can lead to a shift of the position of the samples in the plot towards higher $\mathrm{Nb} / \mathrm{Y}$ ratios. Cor-

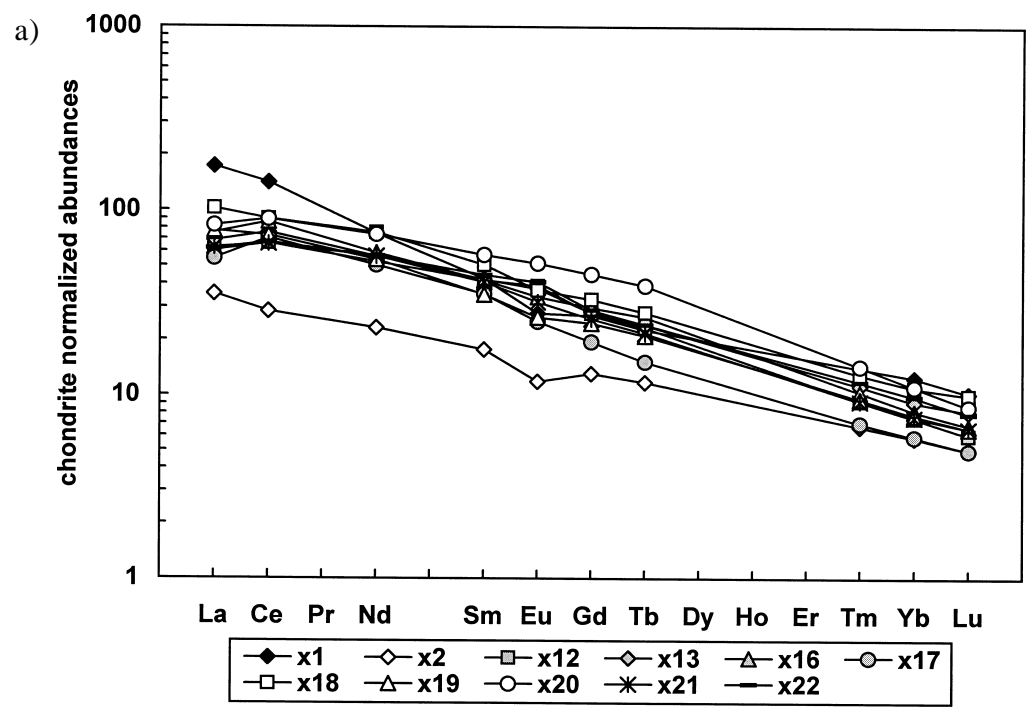

b)
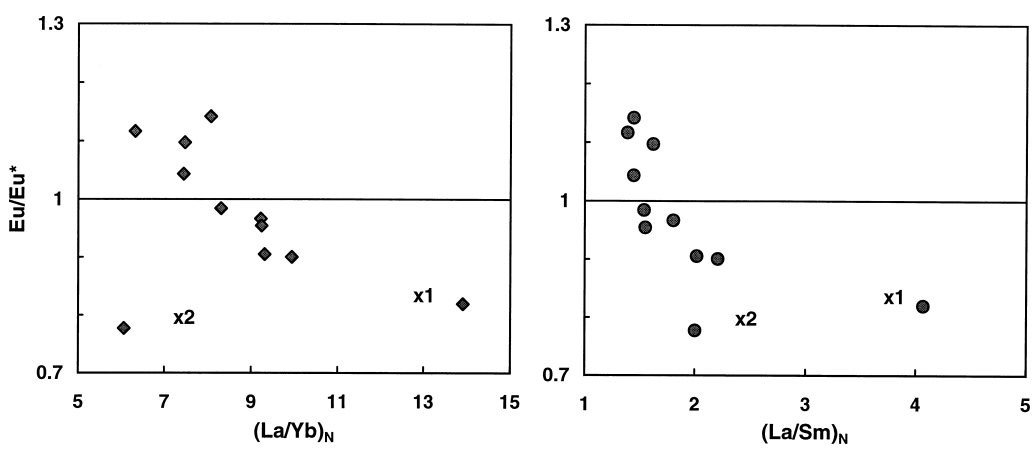

Fig. 5. a) Chondrite-normalized rare earth element abundance patterns of eleven bentonites from the Anthering Formation. Data obtained by INAA, normalization factors by Taylor and McLennan (1985). Samples x1 and x2 show distinctively different patterns compared to the majority of the bentonites. $b)$ Chondrite-normalized La/Yb and La/Sm ratios versus Eu/Eu* of bentonite layers from Anthering. Most samples show only minor Eu-anomalies, whereas $x 1$ and $x 2$ have high depletions in Eu. Sample $x 1$ has a much steeper slope on the normalized REE diagram compared to all other samples, which is reflected by higher La/Sm and La/Yb ratios. 


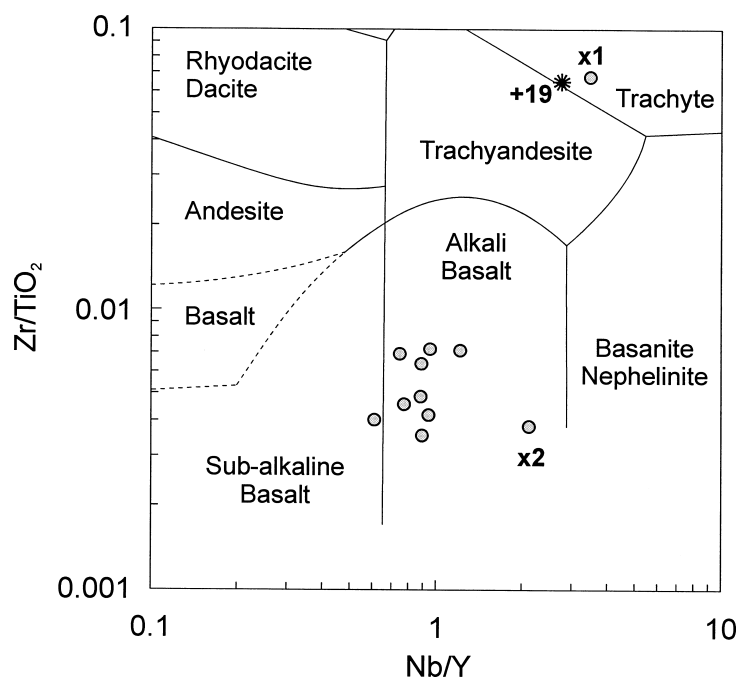

Fig. 6. $\mathrm{Nb}-\mathrm{Y}$ vs. $\mathrm{Zr}-\mathrm{TiO}_{2}$ diagram to determine the magma origin of ash layers from the Anthering formation (after Winchester and Floyd, 1977). Sample x1 (and x2) have a distinct different origin compared to all other ash layers. For comparison with the Danish ash series sample +19 from the Fur formation (Schmitz and Asaro, 1996) is plotted. A common source of $x 1$ and +19 is very likely, as was previously suggested by Egger et al. (2000).

rection of Y-losses would lead to most of the Anthering bentonites to shift to the tholeiitic field, and sample $\mathrm{x} 1$ would then indicate a trachyandesitic source. In the Danish ash series one trachytic ash layer can be correlated to bentonite $\mathrm{x} 1$ by comparing the immobile contents (e.g., $\mathrm{Nb}$ vs. $\mathrm{TiO}_{2}$ in Fig. 4), whereas most samples are FeTitholeiites. Sample $\mathrm{x} 1$ is the lowermost and thickest ash layer within the Anthering formation, and sample +19 forms the base of the so-called "positive" ash series of the Fur formation. The whole series of ashes found in the Danish Paleogene (Ølst and Fur formation) were produced in three volcanic phases. Bøggild (1918) divided the series into two parts, and numbered ash layers of the early phase as negative, and tephra layers from the middle and late phase as the positive series (see also Nielsen and Heilmann-Clausen, 1988). Layer *60 has been shown to be the distant equivalent to layer +19 in the Balder formation based on their anomalous feldspar assemblages (Morton and
Knox, 1990). This correlation is also supported by the data in Figs. 4, 6 and 7. In Fig. 4 these three ash layers plot in a separate position in the low $\mathrm{Ti}$ and high $\mathrm{Nb}$ corner, implying a different volcanic event compared to the other samples. The primitive mantle and MORB-normalized multielement plots (Fig. 7) yield the same conclusion. The samples from layers $x 1,+19$, and $* 60$ have similar patterns, especially concerning the immobile elements $\mathrm{Ti}, \mathrm{Nb}, \mathrm{Hf}, \mathrm{Zr}$, and Ta. Sample $\mathrm{x} 2$, the layer closest to $\mathrm{x} 1$ (distance $\sim 20 \mathrm{~cm}$ ), shows a totally different pattern. In addition to a distinct depletion in the total REE contents, and an enrichment in $\mathrm{Ti}$, this sample has the same distribution pattern as the majority of bentonites investigated in this study (see shaded area in Fig. $5)$.

According to the iridium abundance, $x 1$ (47 \pm $16 \mathrm{ppt}$ ) is the only bentonite with an iridium abundance similar to those determined by Schmitz and Asaro (1996) for the trachytic North Sea layers (0-31 ppt). Thus, the similarity between the layer $\mathrm{x} 1$ from Anthering and the +19 layer $(0 \pm 14 \mathrm{ppt}$ Ir) of the Fur Formation is further confirmed by iridium contents, which are distinctively lower than those from the upper smectite layers (200400 ppt in our study, 100-600 ppt by Schmitz and Asaro, 1996). High enrichments in iridium have been reported from deep mantle basaltic volcanism at Hawaii (Zoller et al., 1983). The suggested fluorine content necessary for the volatilization of Ir as hexafluoride (Toutain and Meyer, 1989) is also apparent in actual volcanic systems off eastGreenland, e.g., the Hekla volcano (Zoller et al., 1983). Elliot et al. (1992) proposed that this volcano is a representative of the spreading system that led to the early Eocene ash series. Therefore, fluorine contents of some thousand ppm, as they are measured today in the exhalations of Hekla, could explain the enrichments of iridium in the tholeiitic ashes. Nevertheless, the question on the special scenario of production of the singular Irdepleted layer within the sequence still remains unsolved.

The Paleocene/Eocene transition, at ca. $55 \mathrm{Ma}$, is marked by a significant ( $c a$. $50 \%$ of species) 


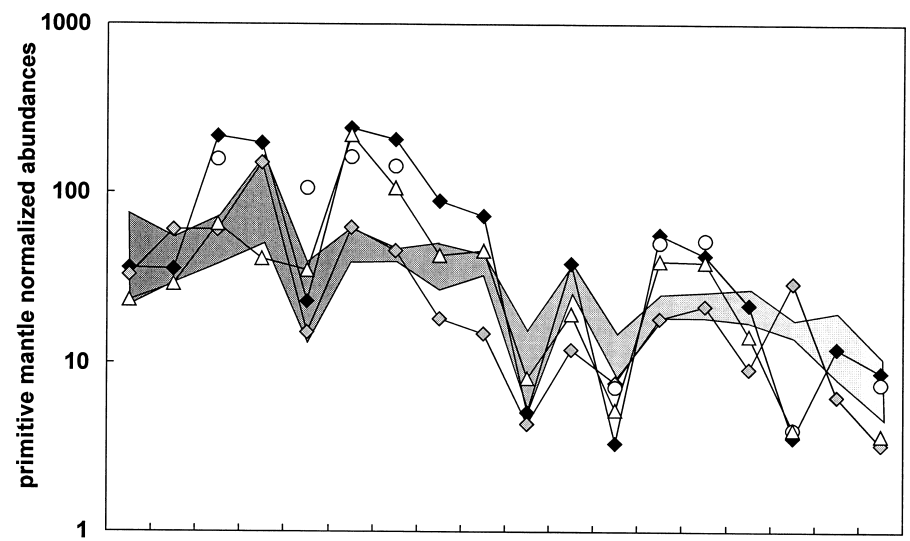

Rb Ba Th U K Ta Nb La Ce Sr Nd P Hf Zr Sm Ti Tb Y

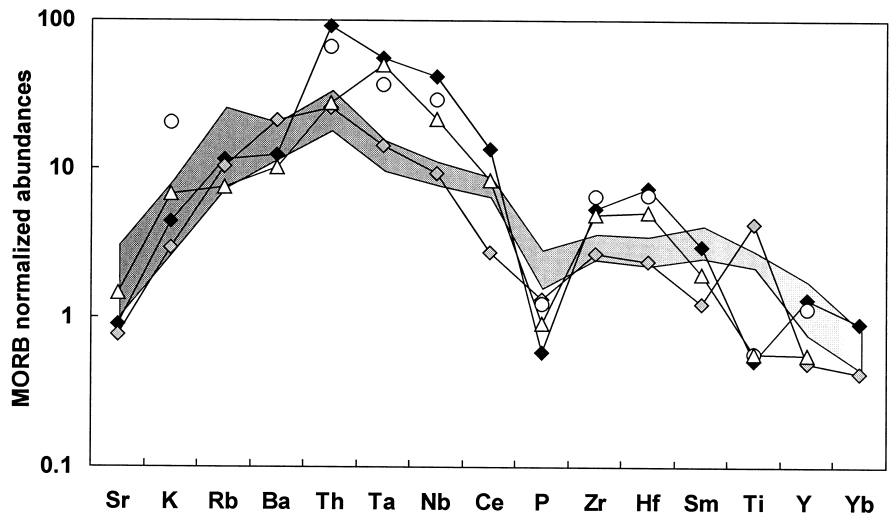

$$
\begin{array}{lllll}
\neg \bullet \mathrm{x} 1 & \diamond \mathrm{x} 2 & \circ+19 & -{ }^{*} 60 \\
\hline
\end{array}
$$

Fig. 7. Normalized multielement patterns. Normalization values from McDonough et al. (1992) for primitive mantle and Pearce (1983) for N-type MORB. Both patterns show the differences between layers $x 1$ and $x 2$ and the rest of analyzed bentonite layers (shaded areas). Layer $x 1$ can be compared to the +19 layer of the Fur Formation in the Northern Sea (Schmitz and Asaro, 1996) and the layer *60 from the Danish Balder Formation (Morton and Knox, 1990).

mass extinction of the benthic foraminifera, which, in contrast, were much less affected by the overall much more severe end-Cretaceous mass extinction (see Hallam and Wignall, 1997). The isotopic evidence indicates that at this time the Earth's climate and the oceans warmed up significantly within a short time period (10 to $20 \mathrm{k} . \mathrm{y}$.), with water temperature in the deep ocean and high-latitude surface water rising by $4^{\circ}$ to $8^{\circ} \mathrm{C}$ (e.g., Kennett and Stott, 1991). The carbon isotopic compositions show an excursion to negative val- ues, as mentioned above. These observations bring on the question regarding the possible cause of the Paleocene/Eocene mass extinction. Norris and Röhl (1999) suggested that catastrophic release of carbon from methan hydrates could have been responsible, whereas Kent et al. (pers. commun., 2002) cite evidence for a possible impact event.

The present data have some relevance for the impact interpretation. A minor Ir anomaly at the Tr-J boundary has recently been interpreted as possible evidence for an impact link. In another 
recent study, Dolenec et al. (2000) report elevated Ir contents at the P-E boundary, and suggest that these data could be consistent with an impact event. However, Dolenec et al. (2000) reported Ir values of $0.1-2.3 \mathrm{ppb}$, which is up to ten times higher than our values (and on par with many K$\mathrm{T}$ boundary layer Ir contents), and could constitute an enormous Ir anomaly, but their analytical methods are not well documented. Thus, their data should be viewed with some suspicion. In contrast, volcanic sources can also be responsible for minor Ir enrichments, as mentioned above, especially if a distinct change in lithology or redox conditions is correlated with the Ir enrichment. In absence of more specific data, such as the interelement ratios of the platinum group elements, or the determination of osmium isotopic ratios, for the Anthering samples, we can neither confirm nor reject a possible extraterrestrial source of the Ir, although the lithological association with bentonites and the multiple occurrences of highIr layers makes an extraterrestrial source unlikely.

\section{Conclusions}

Eleven bentonite samples from the Anthering Formation have been analyzed for their chemical composition to confirm previously established correlations with ash layers from the North sea and Denmark. This investigation included the determination of iridium with highly-sensitive coincidence spectrometry. The previously suggested correlation of the lowermost ash layer (x1) with the North sea and Danish ash series from the Fur and Balder formation by Egger et al. (2000) can be confirmed on the basis of the major and trace element distribution. The chemical composition and the iridium contents of the bentonites from Anthering are similar to those of coeval ash-layers of the North Sea Basin and suggest that both volcanic deposits are derived from the same source of magma. Recently published data on the origin of an older Danish ash layer ( -17 of the Fur-formation) indicate that the Gardiner complex was responsible was this layer (Heister et al., 2002). On the other hand, Heister et al. (2002) also con- clude that the layer +19 can not be connected with this volcanic complex. The data do not provide any compelling evidence for an impact event correlated with the P-E boundary, although we cannot exclude such an interpretation either.

Acknowledgments - This work was supported by the Austrian Science Foundation, grant Y58-GEO (to C.K.). We are grateful to Drs. Hidaka and Ebihara for critical and helpful reviews, and to Prof. J. I. Matsuda for editorial advice.

\section{REFERENCES}

Aubry, M. P. (1996) Towards an upper Paleocene-lower Eocene high resolution stratigraphy based on calcareous nannofossil stratigraphy. Israel Journal of Earth Sciences 44, 239-253.

Aubry, M. P. (2000) Where should the Global Stratotype Section and Point (GSSP) for the Paleocene/Eocene boundary be located? Bull. Soc. géol. France 171, $461-476$

Bøggild, O. B. (1918) The Volcanic Ashes in the 'Mo' Clay. Geological Survey of Denmark, 2nd Series, Vol. 33, 159 pp.

Buchanan, P. C., Koeberl, C. and Reimold, W. U. (1999) Petrogenesis of the Dullstroom formation, Bushveld magmatic province, South Africa. Contrib. Mineral. Petrol. 137, 133-146.

CANMET (1994) Catalogue of Certified Reference Materials. CCRP, Ottawa, Canada, 82 pp.

Christidis, G. E. (1998) Comparative study of the mobility of major and trace elements during alteration of an andesite and a rhyolite to bentonite, in the islands of Milos and Kimolos, Aegean, Greece. Clays Clay Minerals 46, 379-399.

Colodner, D. C., Boyle, E. A., Edmond, J. M. and Thomson, J. (1992) Post-depositional mobility of platinum, iridium and rhenium in marine sediments. Nature 358, 402-404.

Dolenec, T., Pavsic, J. and Lojen, S. (2000) Ir anomalies and other elemental markers near the PalaeoceneEocene boundary in a Flysch sequence from the Western Tethys (Slovenia). Terra Nova 12, 199-204.

Egger, H. (1995) Die Lithostratigraphie der Altlengbach-Formation und der Anthering-Formation im Rhenodanubischen Flysch (Ostalpen, Penninikum). Neues Jahrbuch Geol. Paläont. Abh. 196, 69-91.

Egger, H., Bichler, M., Draxler, I., Homayoun, M., Huber, H., Kirchner, E. Ch., Klein, P. and Surenian, R. (1997) Mudturbidites, black shales and bentonites from the Palaeocene/Eocene boundary: the Anthering 
Formation of the Rhenodanubian Flysch (Austria). Jahrbuch Geologische Bundesanstalt, Wien 140, 2945.

Egger, H., Heilmann-Clausen, C. and Schmitz, B. (2000) The Palaeocene/Eocene-boundary interval of a Tethyan deep-sea section (Austria) and its correlation with the North Sea basin. Bull. Soc. géol. France 171, 207-216.

Egger, H., Homayoun, M. and Schnabel, W. (2002) Tectonic and climatic control of Paleogene sedimentation in the Rhenodanubian Flysch basin (Eastern Alps, Austria). Sedimentary Geology 152, 247-262. Elliot, W. C., Aronson, J. L. and Millard, H. T., Jr. (1992) Iridium content of basaltic tuffs and enclosing black shales of the Balder formation, North Sea. Geochim. Cosmochim. Acta 56, 2955-2961.

Govindaraju, K. (1989) 1989 compilation of working values and sample descriptions for 272 geostandards. Geostand. Newsl. 13, 1-113.

Haase, K. and Devey, C. W. (1994) The petrology and geochemistry of Vesteris Seamount, Norwegian Basin-An intraplate volcano of non-plume origin. $J$. Petrol. 35, 295-328.

Hallam, A. and Wignall, P. B. (1997) Mass Extinctions and Their Aftermath. Oxford University Press, Oxford, U.K., 320 pp.

Heilmann-Clausen, C. and Egger, H. (1997) An ashbearing Paleocene/Eocene sequence at Anthering, Austria: biostratigraphical correlation with the North Sea Basin. Danmarks og Gronlands geol. Unders gelse rapport 87 , p. 13.

Heister, L. E., O'Day, P. A., Brooks, C. K., Neuhoff, P. S. and Bird, D. K. (2002) Pyroclastic deposits within the East Greenland Tertiary flood basalts. J. Geol. Soc., London 158, 269-284.

Jarosewich, E., Clarke, R. S., Jr. and Barrows, J. N. (eds.) (1987) The Allende Meteorite Reference Sample. Smithsonian Contrib. Earth Sci. 27, 1-49.

Katz, M. E., Pak, D. K., Dickens, G. R. and Miller, K. G. (1999) The source and fate of massive carbon input during the latest Paleocene thermal maximum. Science 286, 1531-1533.

Kennett, J. P. and Stott, L. D. (1991) Abrupt deep-sea warming, paleoceanographic changes, and benthic extinctions and the end of the Paleocene. Nature 353, 225-229.

Koeberl, C. (1989) Iridium enrichment in volcanic dust from blue ice fields, Antarctica, and possible relevance to the K/T boundary event. Earth Planet Sci. Lett. 92, 317-322.

Koeberl, C. (1993) Instrumental neutron activation analysis of geochemical and cosmochemical samples: a fast and reliable method for small sample analysis. J. Radioanal. Nucl. Chem. 168, 47-60.
Koeberl, C. (1998) Identification of meteoritical components in impactites. Meteorites: Flux with Time and Impact Effects (Grady, M. M., Hutchison, R., McCall, G. J. H. and Rothery, D. A., eds.), Geological Society (London), Special Publication 140, 133-152.

Koeberl, C. and Huber, H. (2000) Optimization of the multiparameter $\gamma-\gamma$ coincidence spectrometry for the determination of iridium in geological materials. $J$. Radioanal. Nucl. Chem. 244, 655-660.

Knox, R. W. O'B. (1985) Stratigraphic significance of volcanic ash in Paleocene and Eocene sediments at sites 549 and 550. Initial Reports DSDP 80, 845850.

Knox, R. W. O'B. (1998) The tectonic and volcanic history of the North Atlantic region during the Paleocene-Eocene trasition: implications for NW European and global biotic events. Late PaleoceneEarly Eocene Climatic and Biotic Events in the Marine and Terrestrial Records (Aubry, A.-P., Lucas, S. and Berggren, W. A., eds.), 91-102, Columbia University Press, New York.

Knox, R. W. O'B. and Morton, A. C. (1988) The record of early Tertiary North Atlantic volcanism in sediments from the North Sea Basin. Early Tertiary Volcanism and the Opening of the NE Atlantic (Morton, A. C. and Parson, L. M., eds.), Geological Society (London) Special Publication 39, 407-419.

Larsen, L. M., Fitton, J. G., Bailey, J. C. and Kystol, J. (1998) XRF analyses of volcanic rocks from LEG 152 by laboratories in Edinburgh and Copenhagen: implications for the mobility of yttrium and other elements during alteration. Proc. ODP, Sci. Results (Saunders, A. D., Larsen, H. C. and Wise, S. W., Jr., eds.), 152, 425-429, College Station, TX.

Martini, E. (1971) Standard Tertiary and Quaternary calcareous nannoplankton zonation. Proc. 2nd Planktonic Conference, Rome, 739-785.

McDonough, W. F., Sun, S., Ringwood, A. E., Jagoutz, E. and Hofmann, A. W. (1992) K, Rb and Cs in the earth and moon and the evolution of the earth's mantle. Geochim. Cosmochim. Acta 56, 1001-1012.

McLennan, S. M. (1989) Rare earth elements in sedimentary rocks: influence of provenance and sedimentary processes. Geochemistry and Mineralogy of Rare Earth Elements, Reviews in Mineralogy 21 (Lipin, B. R. and McKay, G. A., eds.), 169-200, Mineralogical Society of America, Washington, D.C.

Montanari, A. and Koeberl, C. (2000) Impact Stratigraphy. Lecture Notes in Earth Sciences Vol. 91, Springer Verlag, Berlin-Heidelberg, 364 pp.

Morton, A. C. and Knox, R. W. O'B. (1990) Geochemistry of late Palaeocene and early Eocene tephras from the North Sea basin. J. Geol. Soc., London 147, 425-437. 
Nesbitt, H. W. and Young, G. M. (1984) Prediction of some weathering trends of plutonic and volcanic rocks based on thermodynamic and kinetic considerations. Geochim. Cosmochim. Acta 48, 1523-1534.

Nielsen, O. B. and Heilmann-Clausen, C. (1988) Palaeogene volcanism: the sedimentary record in Denmark. Early Tertiary Volcanism and the Opening of the NE Atlantic (Morton, A. C. and Parson, L. M., eds.), Geological Society (London), Special Publication 39, 395-405.

Norris, R. D. and Röhl, U. (1999) Carbon cycling and chronology of climate warming during the Palaeocene/Eocene transition. Nature 401, 775-778.

Olsen, P. E., Kent, D. V., Sues, H. D., Koeberl, C., Huber, H., Montanari, A., Rainforth, E. C., Fowell, S. J., Szajna, M. J. and Hartline, B. W. (2002) Ascent of dinosaurs linked to an iridium anomaly at the Triassic-Jurassic boundary. Science 296, 1305-1307.

Pearce, J. A. (1983) Role of sub-continental lithosphere in magma genesis at active continental margins. Continental Basalts and Mantle Xenoliths (Hawkesworth, C. J. and Norry, M. J., eds.), 230-249, Shiva Publ., Nantwich.

Reimold, W. U., Koeberl, C. and Bishop, J. (1994) Roter Kamm impact crater, Namibia: Geochemistry of basement rocks and breccias. Geochim. Cosmochim. Acta 58, 2689-2710.

Ritchie, J. D. and Hitchen, K. (1996) Early Paleogene offshore igneous activity to the northwest of the UK and its relationship to the North Atlantic igneous province. Correlation of the Early Paleogene in
Northwest Europe (Knox, R. W. O'B., Corfield, R. M. and Dunay, R. E., eds.), Geological Society (London), Special Publication 101, 63-78.

Schmitz, B. and Asaro, F. (1996) Iridium geochemistry of volcanic ash layers from the early Eocene rifting of the northeastern North Atlantic and some other Phanerozoic events. Geol. Soc. Amer. Bull. 108, 489504.

Taylor, S. R. and McLennan, S. M. (1985) The Continental Crust: Its Composition and Evolution. Blackwell Scientific Publications, Oxford, 312 pp.

Toutain, J. P. and Meyer, G. (1989) Iridium bearing sublimates at a hot-spot volcano (Piton de la Fournaise, Indian Ocean). Geophys. Res. Lett. 16, 1391-1394.

Winchester, J. A. and Floyd, P. A. (1977) Geochemical discrimination of different magma series and their differentiation products using immobile elements. Chem. Geol. 20, 325-343.

Winkler, W., Galetti, G. and Maggetti, M. (1985) Bentonite im Gurnigel-, Schlieren-, und Wägital-Flysch: Mineralogie, Chemismus, Herkunft. Eclogae Geol. Helv. 78, 545-564.

Zielinski, R. A. (1982) The mobility of uranium and other elements during alteration of rhyolite ash to montmorillonite: a case study in the Troublesome Formation, Colorado, U.S.A. Chem. Geol. 35, 185204.

Zoller, W. H., Parrington, J. R. and Kotra, J. M. P. (1983) Iridium enrichment in airborne particles from Kilauea volcano. Science 222, 1118-1121. 